Ewa Forma ${ }^{1}$, Magdalena BernaciaK ${ }^{1}$, Hanna Romanowicz-MaKowsKa ${ }^{2}$ \& MAGDALENA BRYŚ ${ }^{1}$

${ }^{1}$ Department of Cytobiochemistry, University of Łódź, Pomorska 141/143, 90-236 Łódź, Poland, eforma@biol.uni.lodz.pl

${ }^{2}$ Department of Clinical Pathomorphology, Polish Mother's Memorial Hospital, Research Institute, Rzgowska 281/289, 93-338 Łódź, Poland

\title{
RT-PCR ANALYSIS OF TOPBP1 GENE EXPRESSION IN HEREDITARY BREAST CANCER
}

\begin{abstract}
Hereditary predisposition to breast cancer determined in large part by loss of function mutations in one of two genes BRCA1 and BRCA2. Besides BRCA1 and BRCA2 other genes are also likely to be involved in hereditary predisposition to breast cancer. TopBP1 protein is involved in DNA replication, DNA damage checkpoint response and transcriptional regulation. Expression of TopBP1 gene at the mRNA level was analyzed by semiquantitative reverse transcription-polymerase chain reaction (RT-PCR) in 94 samples of hereditary breast cancer. Analysis of TopBP1 mRNA level showed that expression of TopBP1 is significantly downregulated in poorly differentiated breast cancer (grade III according BloomRichardson system $(\mathrm{P}<0.05)$.
\end{abstract}

Key words: TopBP1, gene expression, RT-PCR, hereditary breast cancer

\section{INTRODUCTION}

Hereditary breast and ovarian cancer syndrome is an inherited cancer susceptibility syndrome. The hallmarks of this syndrome are multiple family members with breast or/and ovarian cancer, the presence of both breast and ovarian cancer in a single individual, and early age of breast cancer onset (LU et al. 2009). 
Breast and ovarian cancers are among the most common malignancies of women in Western countries. About $5-10 \%$ of the cases are considered familial, and $40-$ $50 \%$ of them can currently be explained by mutations in two main susceptibility genes, BRCA1 and BRCA2. Of the remaining cases no more than $5 \%$ are caused by defects in other studied genes, such as TP53, PTEN, ATM and CHK2 (KARPPINEN et al. 2006; EASTON 1999). TopBP1 (topoisomerase II $\beta$ binding protein 1) displays structural as well as functional similarities with BRCA1, and both proteins have been suggested to function partly in the same cellular processes (KARPPINEN et al. 2006). Based on its biological significance KARPPINEN et al. (2006) suggested that TopBP1 is a plausible susceptibility gene for hereditary breast and/or ovarian cancer. Aberrant expression of TopBP1 may be involved in the deregulation of processes controlled by this protein and have pathological consequences. The aim of this study was to investigate the expression of TopBP1 at the mRNA level in hereditary breast cancer.

\section{MATERIALS AND METHODS}

\subsection{Sample collection}

Samples of 94 hereditary breast cancers were obtained from patients (age range 28 - 67 years) undergoing surgery for breast neoplasms in Polish Mather's Memorial Hospital, Poland. The inclusion criteria were: (1) at least one first-degree relative with breast cancer, regardless of age, or (2) breast cancer diagnosed below 40 years of age. None of the patient received neoadjuvant endocrine therapy, chemotherapy and radiotherapy. The pathological evaluation report was obtained for each patient (Table 1). Immediately after resection, samples of breast cancer tissue were fixed in $10 \%$ neutral buffered formalin and embedded in paraffin blocks following standard histological protocols. For our studies tissue sections were cut from the blocks with a microtome blade, extra paraffin was removed, and tissue sections was placed in a $1.5-\mathrm{ml}$ microcentrifuge tube. 
Table 1. Characteristics of patients and tumor samples

\begin{tabular}{|c|c|}
\hline Characteristics & Number of patients \\
\hline \multicolumn{2}{|l|}{ Age at diagnosis } \\
\hline range & $28-67$ \\
\hline mean $\pm \mathrm{SD}$ & $55.3 \pm 8.5$ \\
\hline \multicolumn{2}{|l|}{ Type of cancer } \\
\hline ductal carcinoma & 79 \\
\hline lobular carcinoma & 13 \\
\hline tubular carcinoma & 2 \\
\hline Tumor grade according to & \\
\hline \multicolumn{2}{|l|}{ Bloom-Richardson system } \\
\hline I & 9 \\
\hline II & 64 \\
\hline III & 21 \\
\hline \multicolumn{2}{|l|}{ Lymph node metastasis } \\
\hline No & 52 \\
\hline Yes & 42 \\
\hline \multicolumn{2}{|l|}{ Menopausal status } \\
\hline premenopausal & 55 \\
\hline postmenopausal & 39 \\
\hline \multicolumn{2}{|l|}{ ER status } \\
\hline Negative & 46 \\
\hline Positive & 48 \\
\hline \multicolumn{2}{|l|}{ PR status } \\
\hline Negative & 42 \\
\hline Positive & 52 \\
\hline
\end{tabular}

\subsection{Total RNA extraction and cDNA synthesis}

Xylene deparaffinization: Sections were deparaffinized by two rinses in xylene for $10 \mathrm{~min}$ at room temperature with shaking, followed by centrifugations at 
room temperature for $5 \mathrm{~min}$ at $12,000 \mathrm{~g}$. After deparaffinization, we introduced a rehydratation step (rinsing in 100\% ethanol, 85\%, 70\% ethanol, all prepared with DEPC treated $\mathrm{dH}_{2} \mathrm{O}$, for $5 \mathrm{~min}$ ). The tissue was collected by centrifugation at $12,000 \mathrm{~g}$ for $5 \mathrm{~min}$. After the final wash, alcohol was aspirated and the tissue pellets were resuspended in $500 \mu \mathrm{l}$ of digestion buffer $(10 \mathrm{mM} \mathrm{NaCl}, 500 \mathrm{mM}$ Tris- $\mathrm{HCl}$, $\mathrm{pH}$ 8.0, $25 \mathrm{mM}$ EDTA, 1\% SDS) and $1 \mathrm{mg} / \mathrm{ml}$ proteinase $\mathrm{K}$ was added. Sections were incubated at $45^{\circ} \mathrm{C}$ overnight. Prior to RNA purification, in same samples we inactivated proteinase $\mathrm{K}$ at $97^{\circ} \mathrm{C}$ for $10 \mathrm{~min}$. The digested samples were extracted using TRI Reagent (Sigma Aldrich, USA) according to manufacturer's protocol. RNA was eluted in $20 \mu \mathrm{l}$ RNase-free water, quantified by spectrophotometry at 260 $\mathrm{nm}$ and stored at $-20^{\circ} \mathrm{C}$. RNA with a $260 / 280 \mathrm{~nm}$ ratio in range $1.8-2.0$ was considered high quality. First-strand cDNA was synthesized from each RNA pool using PCR Kit ver. 3.0 (Takara Bio Inc. Japan) according to the manufacturer's instructions. Briefly, $1 \mu \mathrm{g}$ RNA was combined with 2.5 pmol of oligo dT-adapter primer, $4 \mu \mathrm{l}$ of $25 \mathrm{mM} \mathrm{MgCl}_{2}, 2 \mu 110 \times$ RNA PCR buffer, $2 \mu 1$ of $10 \mathrm{mM}$ dNTP mixture, 20 units of RNase inhibitor, 5 units of AMV Reverse Transcriptase XL, and RNase-free water to total volume of $20 \mu \mathrm{l}$. The reaction took place at $42^{\circ} \mathrm{C}$ for 30 min, followed by $95^{\circ} \mathrm{C}$ for $5 \mathrm{~min}$ and $5^{\circ} \mathrm{C}$ for $5 \mathrm{~min}$ in a GeneAmp PCR System 9700 (Perkin-Elmer Co, USA). cDNA was stored at $-20^{\circ} \mathrm{C}$.

\subsection{RT-PCR}

One microliters of cDNA sample was used as a substrate for PCR reaction in a $20 \mu \mathrm{l}$ volume with $1 \mu \mathrm{M}$ of forward and reverse primers, $0.2 \mathrm{mM}$ of each dNTP, $1.5 \mathrm{mM} \mathrm{MgCl} 2,2.0 \mu 110 \times$ PCR buffer (200 mM Tris-HCl, $\mathrm{pH} 8.4,500 \mathrm{mM} \mathrm{KCl}$ ) and 1 units Taq polymerase (Takara Bio Inc., Japan). Specific oligonucleotide primers for TopBP1 were as follows F: 5'GCTTCATCGCTCCTACCTTG3', R: 5'TTCCACCCACTAAATGCTCC3'. Glyceraldehyde-3-phosphate dehydrogenase $(G A P D H)$ with primer sequences F: 5'GAAGGTGAAGGTCGGACTC3', R: 5'GAAGATGGTGATGGGATTTC 3' was used as an endogenous control for the PCR amplifications. PCR reaction was carried out as follows: initial denaturation of $4 \mathrm{~min}$ at $94^{\circ} \mathrm{C}$ ) followed by 40 cycles of $1 \mathrm{~min}$ at $94^{\circ} \mathrm{C}, 30 \mathrm{~s}$ at $53^{\circ} \mathrm{C}$ for $T o p B P 1$ and 
$60^{\circ} \mathrm{C}$ for $\mathrm{GAPDH}$ and $30 \mathrm{~s}$ at $72^{\circ} \mathrm{C}$, final extension step of $10 \mathrm{~min}$ at $72^{\circ} \mathrm{C}$. Negative control and already amplified cDNA were included in all the PCR amplifications. The size of amplified fragments was 210 and $225 \mathrm{bp}$ for TopBP1 and GAPDH, respectively. After amplification $10 \mu \mathrm{l}$ of PCR products were combined with $2 \mu 1$ gel loading buffer and the mixture was separated on a $8 \%$ polyacrylamide gel. The gel was silver stained. For qualitative and quantitative analysis of silver nitrate stained gels video densitometr (Biotec-Fischer, Germany) with the software program Gel-Pro® Analyzer 3.0 (Media Cybemetics, USA) was used. All RT-PCR reactions were repeated 2 times for each samples. The integrated optical density (IOD) of the bands in a digitalized picture was measured. TopBP1 gene expression was determined as the ratio of TopBP1 to GAPDH.

\subsection{Statistical analysis}

All data are presented as mean \pm SEM. Because results obtained from RTPCR were not normally distributed (Kolmogorov-Smirnov test), therefore nonparametric Mann-Whitney U-test (for two categories) and the Kruskal-Wallis test with post hoc multiple comparisons (for three categories) were used. Statistical significance was designated at $\mathrm{P}<0.05$.

\section{RESULTS}

The expression of TopBP1 in hereditary breast cancer was estimated at the mRNA level by semiquantitative RT-PCR analysis with GAPDH applied as a reference gene. Representative electropherogram of TopBP1 mRNA expression in hereditary breast cancer with GAPDH mRNA as standard is presented in Fig. 1. Expression of TopBP1 gene at the mRNA level was observed in 81 of 94 (86.2\%) hereditary breast cancer samples. The comparison of transcript level of TopBP1 gene with clinicopathological parameters of tumors is shown in Table 2, where ratio of integrated optical density TopBP1 to GAPDH representing the mean level of mRNA, are used for statistical analysis. Analysis of TopBP1 mRNA level showed significantly lower expression of TopBP1 in the poorly differentiated hereditary breast cancer (grade III according to Bloom-Richardson scale) in comparison with 
moderately and well-differentiated cancer $(\mathrm{P}<0.05)$. No statistically significant differences occured between TopBP1 mRNA level in grade I and II tumors (Fig. 2).

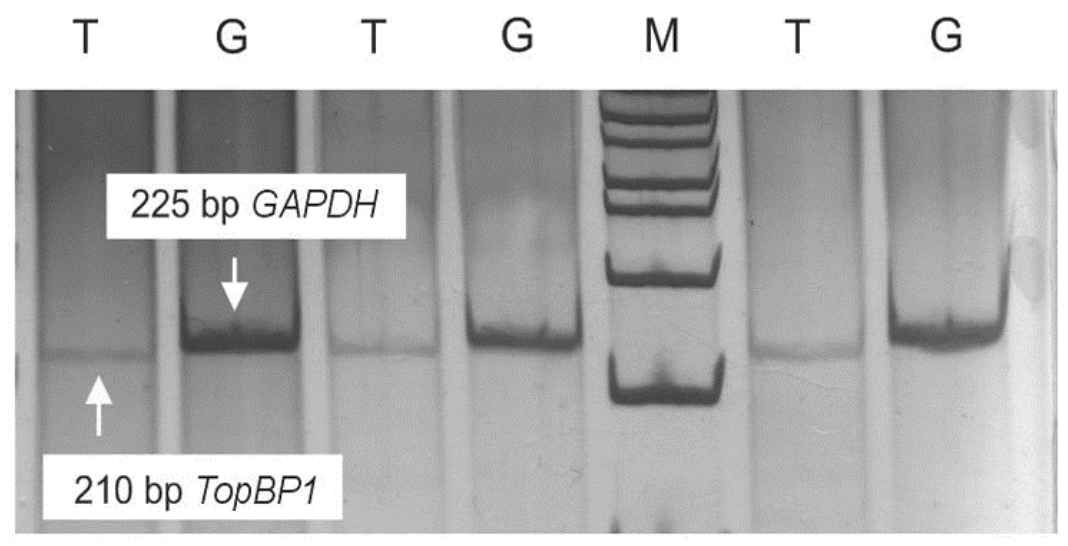

Fig. 1. Representative electropherogram of TopBP1 mRNA expression in hereditary breast cancers with GAPDH mRNA as standard (M molecular weight markers). Amplification products were separated on the $8 \%$ polyacrylamide gel. $\mathrm{T}-\mathrm{TopBP} 1$; $\mathrm{G}-\mathrm{GAPDH} ; \mathrm{M}$ - molecular weight markers.

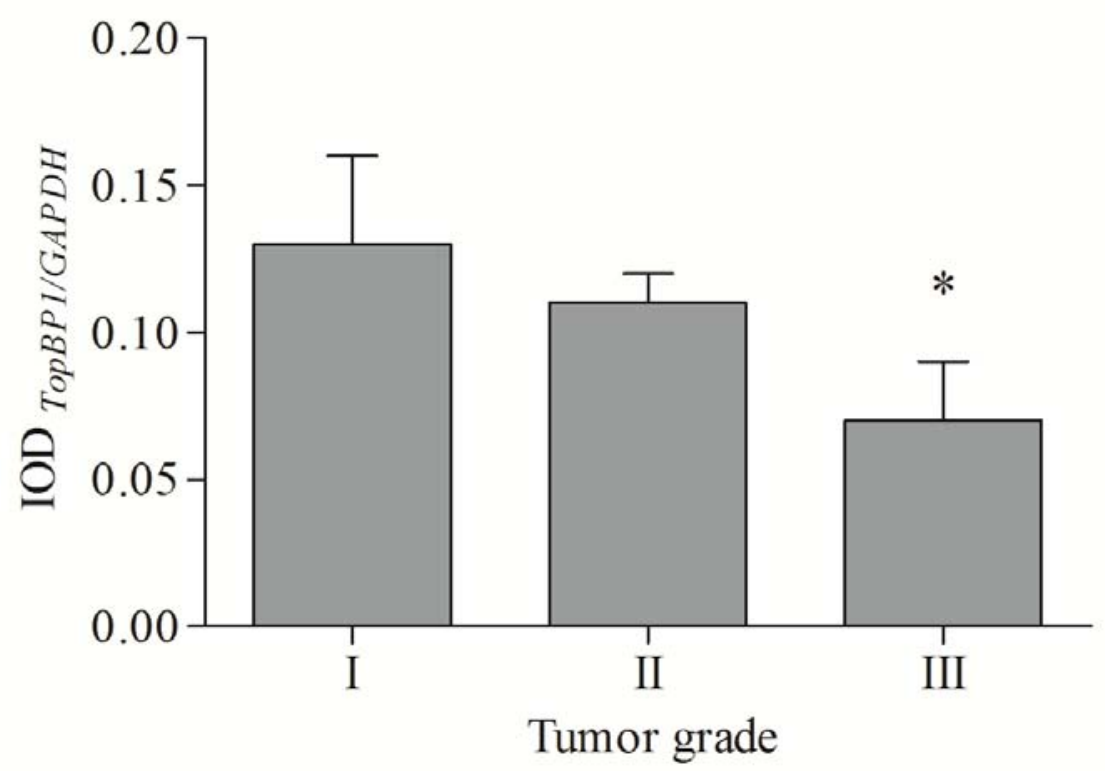

Fig. 2. Expression of TopBP1 mRNA in hereditary breast cancers in relation to tumor grade. Asterisk indicates significant differences at $\mathrm{P}<0.05$. 
There were no significant associations between level of TopBP1 mRNA expression and other clinicopathological parameters, such as estrogen and progesterone receptor status, appearance of metastasis in the axillary lymph nodes and type of cancer.

Table 2. Comparison of the transcript levels of TopBP1 gene with clinicopathological parameters of the tumors

\begin{tabular}{lcc}
\hline $\begin{array}{c}\text { Clinicopathological } \\
\text { features (N) }\end{array}$ & $\begin{array}{c}\text { Semiquantitative } \\
\text { RT-PCR }\end{array}$ & $\mathrm{P}$ \\
\hline Type of cancer & IOD $_{\text {TopBP1/GAPDH })}$ & \\
ductal carcinoma (79) & $0.14 \pm 0.01$ & 0.45 \\
lobular carcinoma (13) & $0.12 \pm 0.02$ & \\
Tumor grade & & \\
I (9) & $0.13 \pm 0.03$ & \\
II (64) & $0.11 \pm 0.01$ & \\
III (21) & $0.07 \pm 0.02$ & \\
Lymph node status & & 0.67 \\
No (52) & $0.13 \pm 0.01$ & \\
Yes (42) & $0.11 \pm 0.01$ & \\
ER status & & 0.64 \\
Negative (46) & $0.12 \pm 0.01$ & \\
Positive (48) & $0.10 \pm 0.01$ & \\
PR status & & \\
Negative (42) & & \\
Positive (52) & & \\
\hline
\end{tabular}

\section{DISCUSSION}

TopBP1 protein plays a key role in various aspects of DNA metabolism. It is required for the initiation of DNA replication, the maintenance of DNA replication forks when replication is stalled and for DNA damage signaling and checkpoints 
(JEON et al. 2007; KIM et al., 2005; KUMAGAI et al. 2006; LiU et al 2006; Morishima et al. 2007; SCHMIDT et al 2008; YAMMANE et al. 2003). TopBP1 is also involved in the process of mitosis in somatic cells and during meiotic recombination in germ cells (PERERA et al. 2004; REINI et al. 2004). Most of TopBP1 does not colocalize at site of ongoing DNA replication in irradiated cells but is relocalized to stalled replication forks upon DNA damage. The involvement of TopBP1 in DNA replication is supported by the demonstration that incubation of an antibody against the sixth BRCT motif of TopBP1 inhibits replicative DNA synthesis in a in vitro HeLa cell nucleus replication assay (KIM et al. 2004; MAKINEMI et al. 2001). TopBP1 can interact with human polymerase $\varepsilon$, checkpoint protein Rad9, Miz-1, E2F1, human papilliomavirus type 16 (HPV16) transcription/replication factor E2 (BONER et al. 2002; DONALDSON et al. 2007; Delacroix et al. 2007; Herold et al. 2002; LiU et al. 2003, 2004, 2006; MAKINIEMI et al. 2001) . TopBP1 also participates in ATR activation in ATRIPdependent manner (Burrows, Elledge 2008; Cimprich, Cortez 2008; Kumagai et al. 2006; LEE et al. 2007). In addition to control DNA replication, TopBP1 is also required for cell survival. Inhibition of TopBP1 expression induces apoptosis. TopBP1 is involved in several important aspects of regulation cell growth (LIU et al. 2003; YAMANE et al. 2002). The aim of this study was investigate the transcript level of TopBP1 gene. Analysis of TopBP1 expression shown that tumor progression is accompanied by a decrease of TopBP1 mRNA level. Expression of TopBP1 is regulated by $\mathrm{Rb} / \mathrm{E} 2 \mathrm{~F} 1$ and is induced when cells enter into S phase (LIU et al. 2004, 2009; YoshidA, INOUE 2004). Therefore, disruption of Rb/E2F1 pathway can lead to overexpression of TopBP1 protein in breast cancers. In the other hand, TopBP1 regulates activity of E2F1 and overexpression of TopBP1 suppressed E2F1 transcriptional activity (LIU et al. 2003, 2004). Thus, decreased transcriptional activity of E2F1 by TopBP1 can repress the expression of E2F1 target genes, including TopBP1. In the other hand, downregulation of TopBP1 mRNA expression may be caused by aberration expression of E2F1. Many studies have found that expression of E2F1 protein in breast cancer tended to decreased as the grade 
increase (Ho et al. 2001; KWON et al. 2009). However, regulation of TopBP1 expression will need to be studied.

\section{Acknowledgements}

This work was supported by the grant of Integrated Operational Program for Regional Development, ZPORR (grant no. 10/S-UŁ/2009). The project was also cofounded by the European Union under the European Social Fund, POKL "Human Best Investment!”.

\section{REFERENCES}

Boner, W., TAylor, E.R., Tsirimonaki, E., Yamane, K., CAmpo, M.S., MoRGAN, I.M. 2002. A functional interaction between the human papillomavirus 16 transcription/replication factor E2 and the DNA damage response protein TopBP1. J. Biol. Chem. 277: 22297-22303.

Burrows, A.E., Elledge, S. 2008. How ATR turns on: TopBP1 goes on ATRIP with ATR. Genes Dev. 22: 1416-1421.

CIMPRICH, K.A., CORTEZ, D. 2008. ATR: an essential regulator of genome integrity. Nature Rev. Mol. Cell Biol. 9: 616-627.

DelacroiX, S., Wagner, J.M., Kobayashi, M., Yamamoto, K.I., Karnitz, L.M. 2007. The Rad9-Hus1-Rad1 (9-1-1) clamp activates checkpoint signaling via TopBP1. Genes Dev. 21: 1472-1477.

Donaldson, M.M., Boner, W., Morgan, I.M. 2007. TopBP1 regulates human papillomavirus type 16 E2 interaction with chromatin. J. Virol. 81: 4338-4342.

EASTON, D.F. 1999. How many more breast cancer predisposition genes are there? Breast Cancer Res. 1: 14-17.

Herold, S., Wanzel, M., Beuger, V., Frohme, C., Beul, D., Hillukkala, T., Syvaoja, J., Saluz, H.P., Haenel, F., EiLERS, M. 2002. Negative regulation of the mammalian UV response by Myc through association with Miz-1. Mol. Cell 10: 509-521. 
Ho, G.H., Calvano, J.E., Bisogna, M., Van Zee, K.J. 2001. Expression of E2F-1 and E2F-4 is reduced in primary and metastatic breast carcinomas. Breast Cancer Res. Treat. 69: 115-122.

Jeon, Y., Lee, K.Y., Ko, M.J., Lee, Y.S., Kang, S., Hwang. D.S. 2007. Human TopBP1 participates in cyclinE/CDK2 activation and preinitiation complex assembly during G1/S transition. J. Biol. Chem. 282: 14882-14890.

Karppinen, S.M., ErkKo, H., Reini, K., Pospiech, H., Heikkinen, K., Rapakko, K., Syvaoja, J.E., Winqvist, R. 2006. Identification of a common polymorphism in the TopBP1 gene associated with hereditary susceptibility to breast and ovarian cancer. Eur. J. Cancer. 42: 2647-2652.

Kim, J.E., McAvoy, S.A., Smith, D.I., Chen, J. 2005. Human TopBP1 ensures genome integrity during normal S phase. Mol. Cel. Biol. 25: 10907-10915.

Kumagai, A., Lee, J., Yoo, H.Y., DunPHY, W.G. 2006. TopBP1 activates the ATRATRIP complex. Cell 124: 943-955.

Kwon, M.J., NAm, E.S., ChO, S.J., PARK, H.R., Shin, H.S., PARK, J.H., PARK, C.H., LEE, W.J. 2009. E2F1 expression predicts outcome in Korean women who undergo surgery for breast cancer. Ann. Surg. Oncol. 17: 564-71.

Lee, J., Kumagai, A., DunPhy, W.G. 2007. The Rad9-Hus1-Rad-1 checkpoint clamp regulates interaction of TopBP1 with ATR. J. Biol. Chem. 282: 2803628044.

LiU, K., Lin, F.T., RupPERT, J.M., Lin, W.C. 2003. Regulation of E2F1 by BRCT domain-containing protein TopBP1. Mol. Cell. Biol. 23: 3287-3304.

LiU, K., LuO, Y., Lin, F.T., LIN, W.C. 2004. TopBP1 recruits BRG1/BRM to repress E2F1-induced apoptosis, a novel pRb-independent and E2F1-specific control for cell survival. Genes Dev. 21: 1472-1477.

LiU, K., PAIK, J.C., WANG, B., Lin, F.T., Lin. W.C. 2006 Regulation of TopBP1 oligomerization by Akt/PKB for cell survival. EMBO J. 25: 4795-4807.

LiU, K., Bellam, N., Lin, H.Y., Wang, B., Stockard, C.R., Geizzle, W.E., Lin, W.C. 2009. Regulation of p53 by TopBP1: a potential mechanism for p53 inactivation in cancer. Mol. Cell. Biol. 29: 2673-2693. 
Lu, K., Kauff, N., Powell, B., Chen, L.M., Cass, I., Lancaster, J. 2009. Hereditary breast and ovarian syndrome, ACOG Practice Bull. Gynecol. Oncol. 113: 6-11.

Makiniemi, M., Hillukkala, T., Tuusa, J., Reini, K., VaAra, M., Huang, D., Pospiech, H., Majuri, I., Westerling, T., Mäkelä, T.P., SyväOJa, J.E. 2001. BRCT domain-containing protein TopBP1 functions in DNA replication and damage response. J. Biol. Chem. 276: 30099-30406.

Morishima, K.I., SaKamoto, S., Kobayashi, J., Izumi, H., Suda, T., Matsumoto, Y., Tauchi, H., Ide, H., Komatsu, K., Matsuura, S. 2007. TopBP1 associates with NBS1 and is involved in homologous recombination repair, Biochem. Biophys. Res. Commun. 362: 872-879.

Perera, D., Perez-Hidalgo, L., Moens, P.B., Reini, K., Lakin, N., Syväoja, J.E., San-Segundo, P.A., Freire, R. 2004. TopBp1 and ATR colocalization at meiotic chromosomes: role of TopBP1/Cut5 in the meiotic recombination checkpoint, Mol. Biol. Cell 15: 1568-1579.

Reini, K., Uitto, L., Perera, D., Moens, P.B., Freire, R., Syväoja, J.E. 2004. TopBP1 localises to centrosomes in mitosis and chromosome cores in meiosis, Chromosoma 112: 323-330.

Schmidt, U., Wollmann, Y., Franke, C., Grosse, F., Saluz, H.P., Hanel, F. 2008. Characterization of the interaction between the human DNA topoisomerase II $\beta$-binding protein 1 (TopBP1) and the cell division cycle protein 45 (Cdc45). Biochem. J. 409: 169-177.

Yamane, K., Chen, J., Kinsella, T.J. 2003. Both DNA topoisomerase II-binding protein 1 and BRCA1 regulate the $\mathrm{G}_{2}-\mathrm{M}$ cell cycle checkpoint. Cancer Res. 63: 3049-3053.

YAmAne, K., Wu, X., Chen, J. 2002. A DNA damage-regulated BRCT-containing protein, TopBP1, is required for cell survival. Mol. Cell. Biol. 22: 555-566.

Yoshida, K., InOUe, I. 2004. Expression of MCM10 and TopBP1 is regulated by cell proliferation and UV irradiation via the E2F1 transcription factor. Oncogene 23: $6250-6260$. 